\title{
Exploration into Bringing Li Nationality's Folk Fairy Tales to Chinese Classes in Primary Schools
}

\author{
Jiafa Wang ${ }^{1, a^{*}}$ and Guiping Lian ${ }^{2, b}$ \\ ${ }^{1}$ Professor of School of Education, Hainan Tropic Ocean University \\ ${ }^{2}$ Graduate of 2015 from School of Education, Hainan Tropic Ocean University \\ awangj168@163.com, ${ }^{b} 545170267 @ q q . c o m$ \\ * The corresponding author
}

Keywords: Li nationality's folk fairy tale; Chinese of primary schools; Class teaching

\begin{abstract}
This paper starts from the definition of the concept of fairy tales and the concept of Li nationality's folk fairy tales to analyze the aesthetic characteristics of Li nationality's folk fairy tales first, and then explores the necessity and possibility of bring Li nationality's folk fairy tales into Chinese classes in primary schools.
\end{abstract}

\section{Introduction}

$\mathrm{Li}$ is a unique nationality with a long history of its national culture, various forms and rich contents of literatures as well as its unique characteristics, which is especially true for its folk fairy tales. Therefore, if its folk fairy tales can be taught at the Chinese classes of primary schools, it will play a positive role in the new curriculum reform and add color to poetry teaching of Chinese classes at primary schools with important significance on the healthy development of children, both physically and mentally. However, relevant data show that there are very scare researches both in China and abroad into how to bring Li nationality's folk fairy tales into Chinese class at primary schools, so this paper intends to explore this aspect.

\section{Analysis of the Concept of Fairy Tales and Definition of the Concept of Li Nationality's Folk Fairy Tales}

Fairy tale is a genre of children's literature, and the name "fairy tale" appeared in late Qing Dynasty in China. In 1909, the Commercial Press published the Fairy Tales series edited by Sun Yuxiu" [1] Since then, the word "fairy tale" began to prevail. At that time, fairy tales were mainly various stories for children, and after the Chinese New Culture Movement, people began to use the vernacular and abandon the tedious ancient Chinese characters, so a huge amount of foreign literatures (fairy tales) were translated into Chinese, and fairy tales written by Chinese writers also began to appear. Since then, researches into fairy tales has been becoming increasingly in-depth.

There are various concepts of fairy tale. $\mathrm{Ci} \mathrm{Hai}$ interprets it as "a kind of children literature that creates characters through rich imagination, fantasy and exaggeration. Fairy tales are bizarre, vivid and plain stories full of twists and turns reflecting the true life. With personified characters, fairy tales are suitable for children with the ultimate goal of educating children." [2] However, in Taiwan's Chinese Children's Encyclopedia, "Targeting at children, fairy tales are fictitious according to children's thinking characteristics with vivid and interesting stories and treating everything as a person. Besides, these things can communicate and interact with each other, and all the good things ca be realized." [3]

In terms of the explanation of fairy tales, scholars hold different opinions. Wang Quangen describes that "fairy tales are a kind of virtual work to express and satisfy people's wishes, especially children's wishes through the aesthetic means of fantasy." [4] Fang Weiping explains that "fairy tales are books written for children represented by children's literatures and stories, including picture stories, myths, life stories ad fables, etc." [5] Hong Xuntao also wrote: "Fairy tales 
are a genre of children's literature and their main techniques of expression include fantasy, hyperbole and personification." [6]

All the above explanations are rational to some extent, and differences are caused by different angles. According to previous definitions, Li nationality's folk fairy tales can be defined as: "a literature genre recorded through word of mouth and in Chinese characters suitable for children to listen, speak and read. They are various bizarre stories full of myth ad national characteristics created by Li nationality's ancestors according to their current life and expectation for better life through rich imagination, fantasy and hyperbole."

\section{Aesthetical Features of Li Nationality's Folk Fairy Tales}

Simple and Plain Language. Li nationality's folk fairy tales are clearly and orderly described in simple language without mincement. For example, in God of Power, "turn hair into tropic natural forest, and use blood and sweat to construct Wanquan River, Changhua River and Nandu River". The description is simple, clear, plain and vivid while full of the flavor of life. In Story of Timu Bird, there is description like this: "Mum, mum, don't go, don't go, your son is wrong, and I am wrong..." Although they are just a few words, they are in simple and concise language full of the flavor of life, demonstrating the features classic Li nationality's oral language, so they are easily understood and accepted by children. In addition, Er Wei describes Er Wei's aunt like this: "her eyes turn red when she sees money, so she is so snobbish", etc. Obviously, they are colloquial and easy to be understood. Li nationality does not have their own characters, so their stories are passed down through word-of-mouth, which are generally simple and plain. Hence, Li nationality's fairy tales have the aesthetic features of simple and concise language.

Legendary and Romantic Stories. Li nationality is a romantic ethnic minority, and their folk stories are also full of legendary and romantic colors. For example, in The Legend of Five Finger Mountain, there is a description like this "In ancient times, there lived an industrious and poor family on the Five Finger Mountain. One night, the father A Duo had a dream that the god told him where there was a gold hoe and sword, so the next day, the father A Duo found a gold hoe and sword according to the god's instruction, and they were no longer poor. However, a villain Hai Wei snatched the gold hoe and sword with his family and killed the man's wife and five sons. When the five brothers were about to die, wolverines, termites and bees from all directions came to kill Hai Wei and his peers and carried a lot of soil and rocks to bury the five brothers' bodies and form the Five Finger Mountain." This not only demonstrates Li nationality's excellent traditions, simple concepts of good and evil in their real life, but also carries their yearning and ideal for a happy life.

There are a lot of Li nationality's folk fairy tales describing love, and these stories are full of twists and turns and moving, such as Gangong Bird, Star Girl, Nuo Shi and Yu Dan, Clothing of Beasts, Wow Bird and Toad Wang Li, etc. In these love stories, people regard diligence as a virtue and labor as happiness; they pursue pure and true love; they are passionate for love till death; they are courageous to overcome difficulties and sweep the thorns on the road of love. In Gangong Bird, the beautiful and smart Li girl Gan Wa bravely resists the oppression of the bully hole in order to stay together with the industrious and brave Bai $\mathrm{He}$ for the happiness of true love; they are unwilling to tolerate their parents' force for a marriage, and are willing to become birds to fly away...Each of these legendary love stories is full of romantic color.

Heroes and Supermen. Li nationality admires heroes and supermen, and this aesthetic feature is prominently reflected in Li nationality's folk fairy tales. Through describing the classic ancestors of Li nationality and making them more mysterious and magnificent, these works focus on creating an ideal hero in the hearts of Li people. The story Brother Constellation tells the story of seven brave brothers, who directly rushed to the heaven to dispute with the Jade Emperor for justice, and then killed and ate the bully pig to live a happy farming life in the heaven. The seven brothers in the story are supermen with the magic power of flying, demonstrating Li people's rebellious spirit to contempt the upper ruling class. The story God of Power extremely exaggerated heroes in the ancestors of $\mathrm{Li}$ people who created the world for their nationality, so it is widely spread in $\mathrm{Li}$ 
nationality. Long, long ago, the earth and heaven were very close to each other with seven suns and moons on the heaven, making people live in misery. Seeing the miserable life of people, the God of Power decided to save people from this misery with his intelligence and power. First of all, he humped up the heaven, and then made a huge bow to shoot down six suns and moons to help people get rid of their misery. In addition, he also created magnificent mountains and rivers on the plain earth according to his aesthetic consciousness with the rainbow as the pole and a huge amount of sands and dirt from the coast to make mountains and hills. Then, he kicked off to create deep rivers and creeks while his sweat became the flowing river water. After creating the world, the God of Power died in a tragic sacrifice.

Rich and Unique Imagination. Li nationality's folk fairy tales contain colorful and rich contents as well as various forms. Exaggeration and imagination are the most commonly used means of artistic expression in Li nationality's folk fairy tales, so they also form another aesthetic feature of Li nationality's folk fairy tales. Imagination is the most commonly used in stories and it is the basis of fairy tales. Without imagination, there will be no fairy tale, because imagination, as a means of artistic expression, is in line with children's thinking characteristics, because during their entire growth, children have insufficient life experience, and they are unable to explain many natural phenomena scientifically and reasonably, so they can only depend on imagination and association to explain these changes. Most of Li nationality's folk fairy tales originated in the primitive social period, when their ancestors were unable to give a scientific and reasonable explanation of many natural phenomena, so they imagined changes in their life combined with their life. Such natural and rich imagination was just in line with children's thinking habits.

Such unique aesthetic features of Li nationality's folk fairy tales in line with the features of Chinese of primary school have provided certain precondition for Li nationality's folk fairy tales to be included into Chinese classes at primary school.

\section{Important Significance of Bringing Li Nationality's Folk Fairy Tales into Chinese Classes at Primary Schools}

Rich Teaching Contents Enhance the Aesthetics of Teaching Chinese at Primary Schools. Folk fairy tales are excellent culture of Li nationality with various aesthetic features, such as rich contents, diverse styles, ups and downs and profound meaning, so they are included in the Chinese classes of primary schools to enrich the teaching contents and add the aesthetics of teaching Chinese. Li nationality's folk fairy tales are in line with children's cognitive thinking features, so they are suitable for children. Chinese teaching at primary schools emphasizes teaching through entertainment and beauty to allow students learn in happiness and enjoy the pleasure of beauty in learning, so it is necessary to add more aesthetic contents that can attract children and make them happy in classroom teaching. Li nationality's folk fairy tales have beautiful plots and rich imagination, so they are the best choice for Chinese textbooks at primary schools.

Expand Children's Imagination and Beneficial for the Development of Children's Thoughts. Children usually have perceptual thinking, so they often think various phenomena in their life with imagination, fantasy and exaggeration. Li nationality's folk fairy tales are extensive and profound and featured by being suitable for children's thinking and habits. For example, God of Power, Tengu, Why Bulls Eat Grass, Gotu Kola, Coconut and Horizon \& Cape, etc. These stories are strange, exaggerated and funny fully of the color of myth with rich imagination, bizarre plot and hyperbole to expand children's imagination, which is beneficial for the development of children's thinking ability.

Inherit Hainan's National Culture and Enrich Teaching Resources. World culture in a period of great integration, global culture, and culture is not only national, but also the world, therefore, maintain and carry forward the national culture is to preserve the cultural heritage of mankind. Claimed the excellent traditional culture of the Chinese nation and development of $\mathrm{Li}$ nationality culture is the culture of the Chinese nation, it is the culture of the peoples of the world, $\mathrm{Li}$ is a minority, in Hainan for generations, its cultural variety, breadth and depth, has a long history. 2008, Li civil fairy tale was included for, Hainan Province, "non-material culture heritage", due to 
Li is a only language and no text of national, it of most culture are is by mouth, face strong of Western culture and Han culture, Li culture of inherited and development on exists has must of difficulty, so will Li civil fairy tale into extracurricular reading or income primary school language textbook, not only can heritage and development Hainan culture, rich Chinese excellent culture, also can rich textbook resources.

Improve Children's Quality and Promote the Construction of "Hainan International Travelling Island". New curriculum requirements: "Chinese course should lay stress on cultivating students ' language quality and improve students ' moral and aesthetic appeal, form a good character and sound personality, full of moral, intellectual, physical, aesthetic and harmonious development. "[7] The moral and aesthetic taste in the end how to train? This and language textbook content of select has major of relationship, language textbook content of select to and children physical and mental development of law phase adapted, Li civil fairy tale not only adapted has children cognitive mind of development, conducive to children thinking of development, most important of is Li civil fairy tale has rich of content, traditional of thought moral concept, sharp of aesthetic features, story plot vivid interesting, can attract children of eye and inspired children reading of interest, on children of thought concept Shang has is big of effect, And improve children's moral and humanistic quality, promote the development of Hainan's education to help Hainan "international tourism island" of the building.

\section{Possibility of Bringing Li Civil Fairy Tales into Chinese Classes of Primary Schools}

Li civil fairy tales' following three conditions have created possibility for them to be included in Chinese classes at primary schools

In Line with the Positioning of Chinese Courses in New Curriculum. Nature of new curriculum for language courses: "the unification of tool character and humane."[8] Called tool is said language is a basic tool of discipline is to express the thoughts and feelings, Exchange and transfer of cultural tools, is the most important communication tools in their lives. Li folk fairy tales is the daily life of the Li nationality people in order to Exchange expression of thoughts and feelings, the ideal life and aesthetic education of children and creativity, has a strong tool, in line with the characteristics of language tools. Humanism as the name suggests is "human nature" and "culture" the combination of a process that is human nature and culture are interdependent. Orientation of Chinese cultural shows concentrating on the development of Chinese teaching and cultivation of spiritual civilization and values development. New curriculum idea and innovation based on the "whole person" development, stressed the Chinese teaching should seek coordination of intelligence and personality development of students. [9] The Li folk fairy tales are rich in various forms, creation fairy tales, fairy tales, fairy tale romance of nature and customs of fairy tales, these tales contain vast amounts of traditional moral values. The children of "whole person" development education and promotion function. The unity of instrumentality and humanity in line with the position requirements.

Suitable for Children's Cognitive Development. Children at low grades do not know many characters, and they like simple and metrical characters, but children at higher grades know more characters, so they will have richer emotions. They like emotional color more rich stories and the curiosity of children in general are very strong, they for phenomenon of life full of curiosity, in the cognitive rules: ascending, from narrow to wide by shallow to deep, from simple to complex. $\mathrm{Li}$ nationality folk fairy tale not only many beautiful and rich characteristics of fairy tales, with terms of endearment, and touching love story.

For example, "God of Power" is the representative work of Li nationality's folk fairy tales with rich connotation and fantastic imagination. It explains the generation of the world in a romantic way, which is in line of children's cognitive development. Folk children's works like the Deer Turns Back, Lei Gonggen, Brave Datuo, Diaoluo Mountain and The Story of Areca have rich emotional colors, bizarre stories while in line with life. They have great aesthetic value, suitable for children's cognitive development. 
In Line with the Requirement of Reforming Textbook Contents in New Curriculum. According to the new curriculum teaching contents reform spirit, 9 suggestions on the preparation of primary school language teaching are put forward. For example, the two such requirements: in order to help students to establish a correct "three outlooks, values, outlook on life and world view, the primary school language teaching should reflect the characteristics of the times and the modern consciousness, pay close attention to the human and the nature, respect the diversity of culture. [10] Third also emphasized the importance of inheriting and carrying forward the excellent culture of the Chinese nation, it is of great significance to enhance the students' sense of patriotism and national pride. [10] Article 4 requirements Chinese teaching should start from the students' cognitive level of combined with the characteristics of the pupils' cognition of the world and the world of imagination and taking into account the characteristics of physical and mental development of students, to stimulate students' interest in learning and creative spirit. [10] According to the needs of the times proposed reform requirements. Li nationality folk fairy tale although old, but also has the spirit of the times of reform, such as A De Brother and Seven Fairy Sisters, it is product of Li and Han cultures. The story of a Li youth Adriano, parents died young, from the lonely, helpless, and later had to in a rich family drudge, and suffered the abuse of rich Adriano from the industrious and brave, honest kind, cutting, archery proficient in everything. One day, the sky of the seven fairies came out to play, fall in love with the beautiful scenery of Li village landscape, in the smallest of the seven fairy sister, on Adriano's misfortune sympathize very much, so he fell in love with honest A De, and with Adriano knot is husband and wife, the installation in the green mountains, and lived a sweet life on the farm. This culture into Chinese teaching, not only can carry forward the Chinese nation's outstanding culture, but can also enhance the students' national pride and patriotism. Therefore, Li nationality folk fairy tales into language teaching in primary schools, in line with the requirements of the spirit of the reform of the new curriculum content of the teaching materials of Chinese.

\section{References}

[1] W.C. Song Introduction to Children's Literature (Shandong People's Press, China 2010) p.89.

[2] Compiled by Editing Committee. Ci Hai (Shanghai Lexicographical Publishing house, China 1999) p.5701.

[3] Y.N. Ren. Children's Literature (Xi'an. Northwestern Polytechnical University Press, China 2010) p. 88.

[4] Q.G. Wang. Children's Literature Textbook (Beijing. Beijing Normal University Press, China 2009) p.142.

[5] W.P. Fang, K.J. Wang. Children's Literature Textbook (Beijing. Higher Education Press, China 2009) p.127.

[6] X.T. Hong. Fairy Tales (Anhui Children's Publishing House, China 1986) p.12.

[7] W.J. Ni. New Chinese Curriculum Teaching Method (Primary School) (Higher Education Press, China 2010) p.12.

[8] Information on http://www.pep.com.cn/xiaoyu/jiaoshi/tbjx/kbjd/jiedu/

[9] Q.Q. Zhong, Y.H. Cui. New Course Concept and Innovation - Textbook for Normal School Students (the 2rd edition) (Higher Education Press, China 2008) p.3-6.

[10]Chinese curriculum standard research group. Full-time Compulsory Education Chinese Curriculum Standard (experimental draft) Part Three. (People's Education Press China. 


\section{Introduction to the Authors:}

Corresponding Author: Wang Jiafa (1955- ), from Lingshui, Hainan. Dean of School of Education, Hainan Tropic Ocean University, Literature Professor, winner of National Social Science Fund. Research Direction: achieved certain results in researching literary aesthetics, especially the study of literary theory textbook, turned $t$ study national aesthetics recently.

Author: Lian Guiping (1991-), female, from Baisha, Haina, graduate of School of Education,Hainan Tropic Ocean University in 2015. 